\title{
Expression of DNA Mismatch Repair Proteins, PD1 and PDL1 in Barrett's Neoplasia
}

\author{
JAMES J. SALLER ${ }^{1}$, LINDA B. MORA ${ }^{2}$, AEJAZ NASIR ${ }^{2}$, ZACHARY MAYER ${ }^{3}$, \\ MOHAMMAD SHAHID ${ }^{2}$ and DOMENICO COPPOLA ${ }^{1,2}$ \\ ${ }^{1}$ Department of Pathology, Moffitt Cancer Center, Tampa, FL, U.S.A.; \\ ${ }^{2}$ Pathology Laboratory, Florida Digestive Health Specialists, Bradenton, FL, U.S.A.; \\ ${ }^{3}$ College of Medicine, University of Florida, Gainesville, FL, U.S.A.
}

\begin{abstract}
Background/Aim: Cancers with a microsatellite instability-high (MSI-H) or deficient mismatch repair (dMMR) status respond to immune checkpoint inhibition (ICI). Regardless of the tumor type, MSI-H/dMMR status is a reliable biomarker for ICI responsiveness. This study aimed at determining the MSI-H status in precursor lesions to esophageal adenocarcinoma (EAC) such as Barrett's esophagus (BE) and BE with either low-grade dysplasia (LGD) or high-grade dysplasia (HGD). Patients and Methods: We performed immunohistochemical staining (IHC) for PMS2, MSH6, PD1, and PD-L1. Results: All cases of BE (50), LGD (48), and HGD (50) had intact PMS2 and MSH6 nuclear expression; were negative for PDI; and had a PD-LI combined positive score (CPS) score $<1$. One EAC case (2\%) was negative for PMS2 nuclear expression. One HGD case (2\%) and two EAC cases (4\%) were PDI positive (CPS score $<1$ applied to PD1). One EAC case (2\%) had a CPS score $>1$, and one EAC case (2\%) was MSI-H. MSI-H tumors usually show PD-L1 expression, although the MSI-H EAC in this study had a PD-L1 CPS score of $<1$. Conclusion: Further studies investigating EAC and its precursor lesions for PDI, $P D-L 1$, and $d M M R$ status may be informative regarding the immunogenicity of the evolution of EAC.
\end{abstract}

Gastroesophageal reflux disease (GERD), which affects nearly 60 million adults in the USA, is a risk factor for development of Barrett's esophagus (BE), affecting nearly 700,000 adults in the USA (1). The current U.S. criteria for diagnosing BE

This article is freely accessible online.

Correspondence to: Domenico Coppola, MD, 11505 Palmbrush Trail, Suite 120, Lakewood Ranch, FL 34202, U.S.A. Tel: +1 9417574800 , Fax: +1 9417574803, e-mail: domenico.coppola@fdhs.com

Key Words: Barrett, neoplasia, proteins, MMR, PD1, PDL1. require the histologic identification of goblet cell intestinal metaplasia $(1,2)$. The prevalence of BE in the USA, as estimated from a simulation model confirmed by Surveillance, Epidemiology, and End Results (SEER) data, is 5.6\% (5.49$5.70 \%$ ) (2). BE is a risk factor for the development of lowgrade dysplasia (LGD), high-grade dysplasia (HGD), and esophageal adenocarcinoma (EAC) (3-5). The 5-year survival rate of EAC patients is still less than $20 \%$ (6).

The use of molecularly targeted agents is under investigation in several clinical trials for the treatment EAC $(7,8)$. However, there are currently targeted therapeutic options that have been approved by the Food and Drug Administration (FDA), which include the monoclonal antibody trastuzumab for patients who have HER2-positive gastroesophageal cancer and have not previously received any treatment (9-12). In addition, according to the results of the REGARD trial the monoclonal antibody ramucirumab, targeting the VEGF/VEGFR2 pathway and inhibiting tumor blood vessel growth, was approved by the FDA for a subset of patients with advanced gastro-esophageal junction (GEJ) adenocarcinoma, after prior treatment with fluoropyrimidineor platinum-based chemotherapy (13).

Another therapeutic strategy that has been deservedly investigated is immune checkpoint inhibition (ICI) via inhibition of programmed cell death protein 1 (PD-1) on activated $\mathrm{T}$ cells, which interacts with programmed cell death ligand 1 or 2 (PD-L1 or PD-L2), and subsequently inhibits T-cell activation (8-10). In tumors with increased immunogenicity, over-expression of PD-L1 is an evolutionary strategy employed by cancer cells to inhibit Tcell immunogenic response $(10,11)$. Studies that utilize ICI to target tumors with an immunogenic phenotype have had promising results. Specifically, investigation of immunogenic tumors exhibiting microsatellite instability-high (MSI-H) has shown that the deficient mismatch repair (dMMR) status has therapy response implications, to the point that, the FDA approved pembrolizumab for metastatic dMMR solid tumors 
agnostic of anatomic site of origin (9-12). PD-L1 protein expression assayed by immunohistochemistry (IHC) is also a valuable biomarker predictive of responsiveness to ICI (Nivolumab and Pembrolizumab), as a combined positive score $(\mathrm{CPS}) \geq 1$ for PD-L1 has been an FDA-approved test [PD-L1 IHC 22C3 pharmDx (Dako North America Inc., Santa Clara, CA, USA)] for several cancer types, including GEJ carcinomas that are not candidates for surgical resection or definitive chemoradiation based on the results of the KEYNOTE-590 study (14). In addition to the MMR status and PD-L1 expression, there are other biologic markers that have shown correlation with tumor immunogenicity such as tumor mutational burden (TMB), tumor-infiltrating lymphocytes (TILs), peritumoral lymphocytes, and/or tumoradjacent lymph node-like structures, deficient DNA damage response/repair (dDDR) and the immunoscore, which is a digital pathology-based assay for the quantification of immune cells such as $\mathrm{CD}^{+}$and $\mathrm{CD}^{+}$lymphocytes (15-17).

Initial studies have demonstrated inter-study variability regarding the rates of $\mathrm{PD}-\mathrm{L} 1$ and $(\mathrm{MSI}-\mathrm{H})$ status in EAC and the precursor lesions from which EAC arises (18-21).

This study was performed to address the unmet need to systematically characterize the prevalence of these key immune biomarkers in EAC and established precursors. In this study, we determined the prevalence of PD-L1 expression in combination with MMR expression status in $\mathrm{BE}, \mathrm{LGD}, \mathrm{HGD}$ and EAC to assess potential response to ICI.

\section{Patients and Methods}

This study was approved by the Moffitt Cancer Center Institutional Review Board (IRB). The clinical records, and hematoxylin and eosin (H\&E) stained sections selected from endoscopic mucosal resection or esophagogastrostomy resection specimens, containing BE, BE-LDG, BE-HGD, and EAC were reviewed.

This study focused on 425 patients of which 198 were selected. Specimens from these patients included: 50 cases of BE, 48 cases of BE with LGD (BE-LGD), 50 cases of BE with HGD (BE-HGD), and 50 cases of invasive EAC. When available, samples of normal gastroesophageal mucosa (NM), were also selected. These tissues were used to build a Barrett's esophagus - tissue microarray (BE-TMA).

The H\&E slides were evaluated by two pathologists (M.S. and D.C.) to confirm the pathologic diagnosis, while overt areas of BE, BE-LGD, BE-HGD, and EAC were annotated. The formalin-fixed paraffin-embedded (FFPE) tissue blocks corresponding to the H\&E slides of the 198 cases were used to produce the BE-TMA.

For analysis of MMR protein expression by IHC, $4 \mu \mathrm{m}$ TMA sections were pretreated and stained using the Benchmark Ultra Ventana platform (Roche Diagnostics, Indianapolis, IN, USA). MMR status was evaluated using "ready to use" (RTU), monoclonal antibodies against PMS2 [Clone EPR3947; Ventana/Roche (Basel, Switzerland)], MSH2 [Clone G219-1129; Ventana/Roche (Basel, Switzerland)] and MLH1 [Clone M1; Ventana/Roche (Basel, Switzerland)], and MSH6 (EPR3945; Nordic Biosite, Taby, Sweden) diluted 1:50. IHC was denoted as negative when all tumor cells showed loss of nuclear staining. Surrounding stromal cells and
Table I. Clinical and pathological findings (adopted from reference 38).

\begin{tabular}{lc}
\hline Age (range) & $41-83$ years \\
Median age & 69 years \\
Gender & \\
Male & 47 \\
Female & 3 \\
Tumor size range (cm) & 0.2 to 7.5 \\
Median (cm) & 2.1 \\
Tumor type (Adenocarcinoma) & \\
Well differentiated & 5 \\
Moderately differentiated & 23 \\
Poorly differentiated & 22 \\
Tumor stage & \\
I & 26 \\
II & 14 \\
III & 9 \\
IV & 1 \\
\hline
\end{tabular}

tumor-initiating cells (TICs) served as internal controls for each TMA core. For immunohistochemical analyses of PD-1 and PD-L1, $4 \mu \mathrm{m}$ tissue sections were pre-treated using the DAKO PT link system (DAKO; Glostrup, Copenhagen, Denmark) and stained in an Autostainer Plus (DAKO) with the anti PD-1 antibody NAT105 (Abcam, Cambridge, MA, USA) diluted 1:50 and the anti PD-L1 (E1L3N; Cell Signaling Technology, Inc. (CST), Danvers, MA, USA) diluted 1:200. The scoring of these stains was performed according to the FDA approved combined positive score (CPS) criteria (22).

\section{Results}

Patients' characteristics are summarized in Table I. The cases of EAC included 47 men and 3 women. The tumor size ranged between 0.2 and $7.3 \mathrm{~cm}$ (median, $2.1 \mathrm{~cm}$ ). Five (5) tumors were well differentiated, 23 were moderately differentiated, and 22 were poorly differentiated. In addition, 26 cases were stage I, 14 cases were stage II, 9 cases were stage III, and 1 case was stage IV. Ten cases had received preoperative adjuvant radio chemotherapy. The tumor stage was assigned according to the $8^{\text {th }}$ edition of the UICC/AJCC TNM classification.

All cases of BE [50], LGD [48], and HGD [50] had an intact nuclear expression of PMS2 and MSH6, were negative for PD1, and had a PD-L1 CPS score $<1$. One case of EAC (2\%) had a loss of nuclear expression of PMS2. One case of HGD (2\%) and two cases of EAC (4\%) were PD1 positive (CPS score $<1$ applied to PD1). One case of EAC (2\%) had a CPS score $>1$, and one case of EAC (2\%) was MSI-H (Figure 1).

\section{Discussion}

In this study, an anti-PD-L1 antibody (E1L3N), was used, which has been shown in a recent study to be comparable to the three clones (22C3, 28.8 and SP142) used in the FDA- 


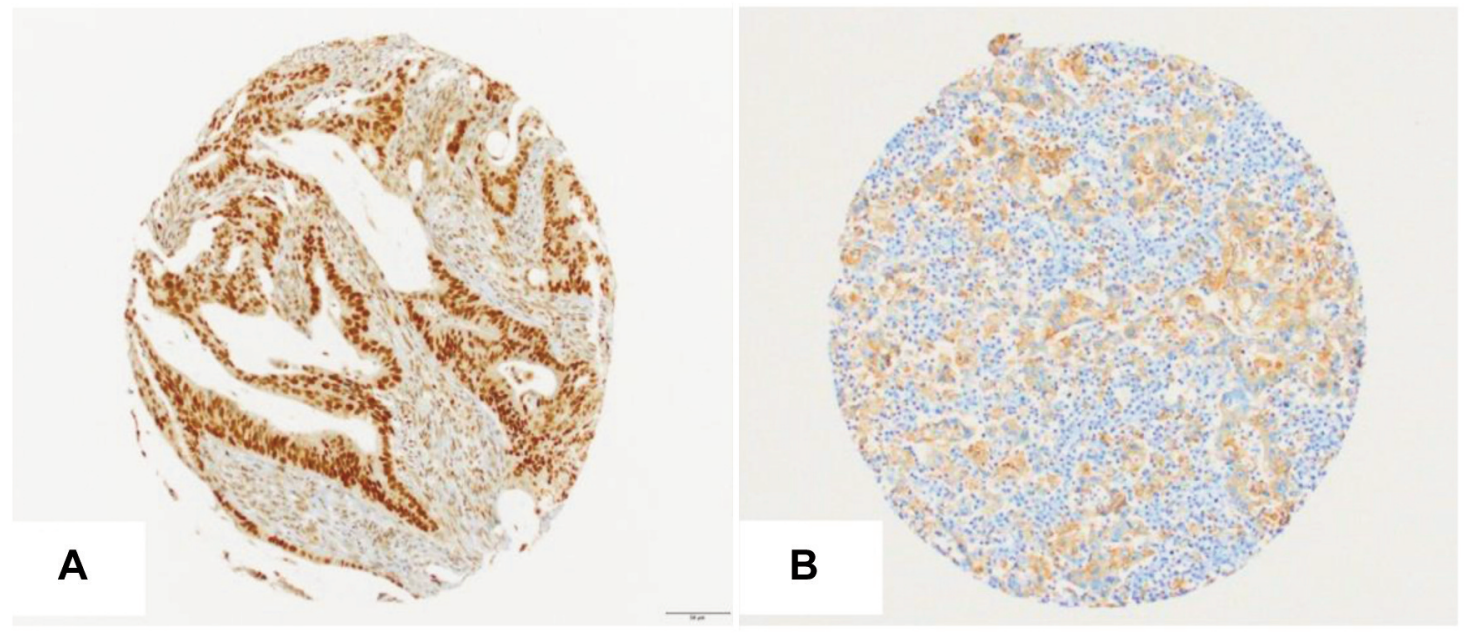

Figure 1. Immunohistochemical results. All cases had an intact nuclear expression of mismatch repair proteins, MSH6 and PMS2. (A) Intact MSH6 protein expression in EAC; (B) A case of EAC exhibiting PDL1 positivity with CPS $>1$.

approved assays for reporting PD-L1 expression by IHC (23).

Expression of PD1 was negative in all cases of BE-LGD and $\mathrm{BE}$, while 1 case $(2 \%)$ of BE-HGD and 2 EAC cases (4\%) were PD1 positive. One EAC case (2\%) was found to be statistically indicative of PD-L1 with a CPS score of greater than 1 .

A recent study by Fassan et al. reported that premalignant esophageal (BE, BE-LGD, BE-HGD), gastric lesions and adenocarcinomas of the GEJ showed PD-L1 expression, as defined by a $C P S \geq 1$, in a significant proportion of cases ( 48 out of $155 ; 31 \%$ ) as well as dMMR in $3.1 \%$ of esophageal lesions (24). Other studies investigating dMMR have demonstrated variability regarding dMMR status in Barrett's related pre-neoplastic lesions. For instance, a recent study of dMMR status in BE reported that $0.8 \%$ of BE cases showed a loss of MLH1 and MSH2 (19). Another study of 70 patients reported that $81.8 \%$ of patients with EAC, $32.4 \%$ of patients with $\mathrm{BE}$ and dysplasia, as well as $50 \%$ of patients with BE had loss of MLH1 expression; while EAC, BE-LGD and BE-HGD did not show loss of MSH2 and MSH6 expression, and $18.2 \%$ BE showed loss of MSH2 and MSH6 expression (25).

In light of the inter-study variability found between previous studies in the literature, the contrast of the relatively high prevalence in positive PD-L1 and dMMR status in these studies, when compared with the lower prevalence in positive PD-L1 and dMMR status in the esophageal pre-neoplastic lesions of this study, suggests that there would be benefit in evaluating an larger diverse cohort to determine the exact prevalence in positive PD-L1 and dMMR status in Barrett's related pre-neoplastic lesions. Moreover, investigation of other genomic alterations within Barrett's related pre-neoplastic lesions would enrich the current understanding the evolution of EAC complementing the studies characterizing Barrett's related pre-neoplastic lesions to date (26-32).

The limitations of this study are primarily based on the interpretation of PD-L1/MMR expression that is limited due to the relatively small size of the TMA cores evaluated, which restricted the amount of tissue available for evaluations, in comparison to the amount of tissue typically available in the specimens from which the TMA cores were derived. Adequate size of the tissue for evaluation is a factor that can mitigate the heterogeneity observed in PD-L1/MMR expression. Given that PD-L1 expression has been shown to be heterogenous in multiple studies, including those demonstrating significant differences in PD-L1 expression between surgically resected specimens and matched biopsies, a confounding factor limiting interpretation of PD-L1 expression is that BE, BE-LGD and BE-HGD tissues were overwhelmingly solely available as biopsies $(33,34)$.

Investigation of ICI responsiveness in EAC has deservedly warranted a number of studies including notably the KEYNOTE-590 study, the findings of which were supportive for the FDA approval of pembrolizumab for EAC or gastroesophageal (GEJ) carcinoma $(14,35,36)$. It is understandable that given the challenge of retrospective studies for pre-neoplastic lesions of EAC, there are limited studies investigating ICI responsiveness of precursor lesions to EAC, which consequently limits the data available regarding these precursor lesions.

Given that the studies available confirm that ICI is effective in the context of dysplasia (37), additional studies corroborating ICI effectiveness in dysplasia have profound implications for potential therapeutic strategies, as there are 
many clinical scenarios wherein concomitant dysplasia may exist separately from a discrete EAC. Thus, precursor lesions (BE, BE-LGD, BE-HGD) of EAC have the potential to be an early target, or a concomitant target with respect to a contemporaneous EAC, which could have clinical implications for PD-L1 expression and MMRd status, although further studies in a larger population should be performed. Given that regression of HGD of the cervix after ICI has been reported, the concept of prophylaxis to future EAC is not an unprecedented concept, although future studies should confirm that there is clear benefit for this approach.

Further studies evaluating the expression of MMR proteins and PD-L1/PD-1 in BE, BE-LGD, BE-HGD, and EAC, using larger endoscopic mucosal resection specimens would facilitate the characterization of the overall prevalence of PD-L1 expression and dMMR status in these lesions. Continued investigation will assist in identifying patients who may be candidates for ICI.

\section{Conflicts of Interest}

The Authors have no conflicts of interest to declare in relation to this study.

\section{Authors' Contributions}

Mohammad Shahid and Zachary Mayer drafted the manuscript, Linda Mora and Aejaz Nasir revised the original draft, James Saller extensively revised the draft and formatted the references, Domenico Coppola planned, originated and supervised the study and provided the pictures.

\section{Acknowledgements}

The project described was supported by Departmental funds of the Department of Pathology, H. Lee Moffitt Cancer Center.

\section{References}

1 Jankowski $\mathrm{M}$ and Wani $\mathrm{S}$ : Diagnostic and management implications of basic science advances in Barrett's esophagus. Curr Treat Options Gastroenterol 13(1): 16-29, 2015. PMID: 25567106. DOI: 10.1007/s11938-014-0040-9

2 Siegel RL, Miller KD and Jemal A: Cancer statistics, 2020. CA Cancer J Clin 70(1): 7-30, 2020. PMID: 31912902. DOI: $10.3322 /$ caac. 21590

3 Lv J, Guo L, Wang JH, Yan YZ, Zhang J, Wang YY, Yu Y, Huang YF and Zhao HP: Biomarker identification and transregulatory network analyses in esophageal adenocarcinoma and Barrett's esophagus. World J Gastroenterol 25(2): 233-244, 2019. PMID: 30670912. DOI: 10.3748/wjg.v25.i2.233

4 Rex DK, Cummings OW, Shaw M, Cumings MD, Wong RK, Vasudeva RS, Dunne D, Rahmani EY and Helper DJ: Screening for Barrett's esophagus in colonoscopy patients with and without heartburn. Gastroenterology 125(6): 1670-1677, 2003. PMID: 14724819. DOI: $10.1053 /$ j.gastro.2003.09.030
5 Cameron AJ, Souto EO and Smyrk TC: Small adenocarcinomas of the esophagogastric junction: association with intestinal metaplasia and dysplasia. Am J Gastroenterol 97(6): 1375-1380, 2002. PMID: 12094853. DOI: 10.1111/j.1572-0241.2002.05669.x

6 Rajendra S, Xuan W, Merrett N, Sharma P, Sharma P, Pavey D, Yang T, Santos LD, Sharaiha O, Pande G, Cosman P, Wu X and Wang B: Survival rates for patients with barrett high-grade dysplasia and esophageal adenocarcinoma with or without human papillomavirus infection. JAMA Netw Open 1(4): e181054, 2018. PMID: 30646096. DOI: 10.1001/jamanetworkopen.2018.1054

7 Derks S, Nason KS, Liao X, Stachler MD, Liu KX, Liu JB, Sicinska E, Goldberg MS, Freeman GJ, Rodig SJ, Davison JM and Bass AJ: Epithelial PD-L2 expression marks Barrett's esophagus and esophageal adenocarcinoma. Cancer Immunol Res 3(10): 1123-1129, 2015. PMID: 26081225. DOI: 10.1158/2326-6066.CIR-15-0046

8 Patel SP and Kurzrock R: PD-L1 expression as a predictive biomarker in cancer immunotherapy. Mol Cancer Ther 14(4): 847-856, 2015. PMID: 25695955. DOI: 10.1158/15357163.MCT-14-0983

9 Patnaik A, Kang SP, Rasco D, Papadopoulos KP, ElassaissSchaap J, Beeram M, Drengler R, Chen C, Smith L, Espino G, Gergich K, Delgado L, Daud A, Lindia JA, Li XN, Pierce RH, Yearley JH, Wu D, Laterza O, Lehnert M, Iannone R and Tolcher AW: Phase I study of pembrolizumab (MK-3475; AntiPD-1 monoclonal antibody) in patients with advanced solid tumors. Clin Cancer Res 21(19): 4286-4293, 2015. PMID: 25977344. DOI: 10.1158/1078-0432.CCR-14-2607

10 Brown JA, Dorfman DM, Ma FR, Sullivan EL, Munoz O, Wood CR, Greenfield EA and Freeman GJ: Blockade of programmed death-1 ligands on dendritic cells enhances T cell activation and cytokine production. J Immunol 170(3): 1257-1266, 2003. PMID: 12538684. DOI: 10.4049/jimmunol.170.3.1257

11 Chen BJ, Chapuy B, Ouyang J, Sun HH, Roemer MG, Xu ML, Yu H, Fletcher CD, Freeman GJ, Shipp MA and Rodig SJ: PD-L1 expression is characteristic of a subset of aggressive B-cell lymphomas and virus-associated malignancies. Clin Cancer Res 19(13): 3462-3473, 2013. PMID: 23674495. DOI: 10.1158/10780432.CCR-13-0855

12 Goldberg SB, Gettinger SN, Mahajan A, Chiang AC, Herbst RS, Sznol M, Tsiouris AJ, Cohen J, Vortmeyer A, Jilaveanu L, Yu J, Hegde U, Speaker S, Madura M, Ralabate A, Rivera A, Rowen E, Gerrish H, Yao X, Chiang V and Kluger HM: Pembrolizumab for patients with melanoma or non-small-cell lung cancer and untreated brain metastases: early analysis of a non-randomised, open-label, phase 2 trial. Lancet Oncol 17(7): 976-983, 2016. PMID: 27267608. DOI: 10.1016/S1470-2045(16)30053-5

13 Fuchs CS, Tomasek J, Yong CJ, Dumitru F, Passalacqua R, Goswami C, Safran H, Dos Santos LV, Aprile G, Ferry DR, Melichar B, Tehfe M, Topuzov E, Zalcberg JR, Chau I, Campbell W, Sivanandan C, Pikiel J, Koshiji M, Hsu Y, Liepa AM, Gao L, Schwartz JD, Tabernero J and REGARD Trial Investigators: Ramucirumab monotherapy for previously treated advanced gastric or gastro-oesophageal junction adenocarcinoma (REGARD): an international, randomised, multicentre, placebocontrolled, phase 3 trial. Lancet 383(9911): 31-39, 2014. PMID: 24094768. DOI: 10.1016/S0140-6736(13)61719-5

14 Sun JM, Shen L, Shah MA, Enzinger P, Adenis A, Doi T, Kojima T, Metges JP, Li Z, Kim SB, Cho BC, Mansoor W, Li SH, Sunpaweravong P, Maqueda MA, Goekkurt E, Hara H, Antunes 
L, Fountzilas C, Tsuji A, Oliden VC, Liu Q, Shah S, Bhagia P, Kato K and KEYNOTE-590 Investigators: Pembrolizumab plus chemotherapy versus chemotherapy alone for first-line treatment of advanced oesophageal cancer (KEYNOTE-590): a randomised, placebo-controlled, phase 3 study. Lancet 398(10302): 759-771, 2021. PMID: 34454674. DOI: 10.1016/S0140-6736(21)01234-4

15 Wilke H, Muro K, Van Cutsem E, Oh SC, Bodoky G, Shimada Y, Hironaka S, Sugimoto N, Lipatov O, Kim TY, Cunningham D, Rougier P, Komatsu Y, Ajani J, Emig M, Carlesi R, Ferry D, Chandrawansa K, Schwartz JD, Ohtsu A and RAINBOW Study Group: Ramucirumab plus paclitaxel versus placebo plus paclitaxel in patients with previously treated advanced gastric or gastrooesophageal junction adenocarcinoma (RAINBOW): a doubleblind, randomised phase 3 trial. Lancet Oncol 15(11): 1224-1235 2014. PMID: 25240821. DOI: 10.1016/S1470-2045(14)70420-6

16 Le DT, Uram JN, Wang H, Bartlett BR, Kemberling H, Eyring AD, Skora AD, Luber BS, Azad NS, Laheru D, Biedrzycki B, Donehower RC, Zaheer A, Fisher GA, Crocenzi TS, Lee JJ, Duffy SM, Goldberg RM, de la Chapelle A, Koshiji M, Bhaijee F, Huebner T, Hruban RH, Wood LD, Cuka N, Pardoll DM, Papadopoulos N, Kinzler KW, Zhou S, Cornish TC, Taube JM, Anders RA, Eshleman JR, Vogelstein B and Diaz LA Jr: PD-1 blockade in tumors with mismatch-repair deficiency. N Engl J Med 372(26): 2509-2520, 2015. PMID: 26028255. DOI: 10.1056/NEJMoa1500596

17 Le DT, Durham JN, Smith KN, Wang H, Bartlett BR, Aulakh LK, Lu S, Kemberling H, Wilt C, Luber BS, Wong F, Azad NS, Rucki AA, Laheru D, Donehower R, Zaheer A, Fisher GA, Crocenzi TS, Lee JJ, Greten TF, Duffy AG, Ciombor KK, Eyring AD, Lam BH, Joe A, Kang SP, Holdhoff M, Danilova L, Cope L, Meyer C, Zhou S, Goldberg RM, Armstrong DK, Bever KM, Fader AN, Taube J, Housseau F, Spetzler D, Xiao N, Pardoll DM, Papadopoulos N, Kinzler KW, Eshleman JR, Vogelstein B, Anders RA and Diaz LA $\mathrm{Jr}$ : Mismatch repair deficiency predicts response of solid tumors to PD-1 blockade. Science 357(6349): 409-413, 2017. PMID: 28596308. DOI: $10.1126 /$ science.aan6733

18 Falkenback D, Johansson J, Halvarsson B and Nilbert M: Defective mismatch-repair as a minor tumorigenic pathway in Barrett esophagus-associated adenocarcinoma. Cancer Genet Cytogenet 157(1): 82-86, 2005. PMID: 15676154. DOI: $10.1016 /$ j.cancergencyto .2004 .08 .003

19 Hewitt LC, Inam IZ, Saito Y, Yoshikawa T, Quaas A, Hoelscher A, Bollschweiler E, Fazzi GE, Melotte V, Langley RE, Nankivell M, Cunningham D, Allum W, Hutchins GG and Grabsch HI: Epstein-Barr virus and mismatch repair deficiency status differ between oesophageal and gastric cancer: A large multi-centre study. Eur J Cancer 94: 104-114, 2018. PMID: 29550565. DOI: 10.1016/j.ejca.2018.02.014

20 Jin $\mathrm{Z}$ and Yoon HH: The promise of PD-1 inhibitors in gastroesophageal cancers: microsatellite instability vs. PD-L1. J Gastrointest Oncol 7(5): 771-788, 2016. PMID: 27747091. DOI: 10.21037/jgo.2016.08.06

21 Momose K, Yamasaki M, Tanaka K, Miyazaki Y, Makino T, Takahashi T, Kurokawa Y, Nakajima K, Takiguchi S, Mori M and Doki Y: MLH1 expression predicts the response to preoperative therapy and is associated with PD-L1 expression in esophageal cancer. Oncol Lett 14(1): 958-964, 2017. PMID: 28693258. DOI: $10.3892 / \mathrm{ol} .2017 .6215$

22 Kulangara K, Zhang N, Corigliano E, Guerrero L, Waldroup S, Jaiswal D, Ms MJ, Shah S, Hanks D, Wang J, Lunceford J,
Savage MJ, Juco J and Emancipator K: Clinical utility of the combined positive score for programmed death ligand-1 expression and the approval of pembrolizumab for treatment of gastric cancer. Arch Pathol Lab Med 143(3): 330-337, 2019. PMID: 30028179. DOI: 10.5858/arpa.2018-0043-OA

23 Tretiakova M, Fulton R, Kocherginsky M, Long T, Ussakli C, Antic $\mathrm{T}$ and Gown A: Concordance study of PD-L1 expression in primary and metastatic bladder carcinomas: comparison of four commonly used antibodies and RNA expression. Mod Pathol 31(4): 623-632, 2018. PMID: 29271413. DOI: 10.1038/modpathol.2017.188

24 Fassan M, Brignola S, Pennelli G, Alberti G, Angerilli V, Bressan A, Pellino A, Lanza C, Salmaso R, Lonardi S, Pucciarelli S, Spolverato G, Scarpa M, Realdon S, Farinati F, Luchini C, Rugge $\mathrm{M}$ and Loupakis F: PD-L1 expression in gastroesophageal dysplastic lesions. Virchows Arch 477(1): 151-156, 2020. PMID: 31724072. DOI: 10.1007/s00428-019-02693-8

25 Markoš P, Brčić I, Brčić L, Jakić-Razumović J and Pulanić R: Microsatellite instability in metaplasia-dysplasia-adenocarcinoma sequence of Barrett esophagus: a retrospective study. Croat Med J 59(3): 100-107, 2018. PMID: 29972732. DOI: 10.3325/cmj.2018. 59.100

26 Newell F, Patel K, Gartside M, Krause L, Brosda S, Aoude LG, Loffler KA, Bonazzi VF, Patch AM, Kazakoff SH, Holmes O, Xu Q, Wood S, Leonard C, Lampe G, Lord RV, Whiteman DC, Pearson JV, Nones K, Waddell N and Barbour AP: Complex structural rearrangements are present in high-grade dysplastic Barrett's oesophagus samples. BMC Med Genomics 12(1): 31, 2019. PMID: 30717762. DOI: 10.1186/s12920-019-0476-9

27 Stachler MD, Camarda ND, Deitrick C, Kim A, Agoston AT, Odze RD, Hornick JL, Nag A, Thorner AR, Ducar M, Noffsinger A, Lash RH, Redston M, Carter SL, Davison JM and Bass AJ: Detection of mutations in Barrett's esophagus before progression to high-grade dysplasia or adenocarcinoma. Gastroenterology 155(1): 156-167, 2018. PMID: 29608884. DOI: 10.1053/j.gastro.2018.03.047

28 Killcoyne S and Fitzgerald RC: Evolution and progression of Barrett's oesophagus to oesophageal cancer. Nat Rev Cancer 21(11): 731-741, 2021. PMID: 34545238. DOI: 10.1038/s41568021-00400-x

29 Gharahkhani P, Fitzgerald RC, Vaughan TL, Palles C, Gockel I, Tomlinson I, Buas MF, May A, Gerges C, Anders M, Becker J, Kreuser N, Noder T, Venerito M, Veits L, Schmidt T, Manner H, Schmidt C, Hess T, Böhmer AC, Izbicki JR, Hölscher AH, Lang H, Lorenz D, Schumacher B, Hackelsberger A, Mayershofer R, Pech O, Vashist Y, Ott K, Vieth M, Weismüller J, Nöthen MM, Barrett's and Esophageal Adenocarcinoma Consortium (BEACON), Esophageal Adenocarcinoma GenEtics Consortium (EAGLE), Wellcome Trust Case Control Consortium 2 (WTCCC2), Attwood S, Barr H, Chegwidden L, de Caestecker J, Harrison R, Love SB, MacDonald D, Moayyedi P, Prenen H, Watson RGP, Iyer PG, Anderson LA, Bernstein L, Chow WH, Hardie LJ, Lagergren J, Liu G, Risch HA, Wu AH, Ye W, Bird NC, Shaheen NJ, Gammon MD, Corley DA, Caldas C, Moebus S, Knapp M, Peters WHM, Neuhaus H, Rösch T, Ell C, MacGregor S, Pharoah P, Whiteman DC, Jankowski J and Schumacher J: Genome-wide association studies in oesophageal adenocarcinoma and Barrett's oesophagus: a largescale meta-analysis. Lancet Oncol 17(10): 1363-1373, 2016. PMID: 27527254. DOI: 10.1016/S1470-2045(16)30240-6

30 Grady WM and Yu M: Molecular evolution of metaplasia to adenocarcinoma in the esophagus. Dig Dis Sci 63(8): 2059-2069, 2018. PMID: 29766388. DOI: 10.1007/s10620-018-5090-8 
31 Yu M, Maden SK, Stachler M, Kaz AM, Ayers J, Guo Y, Carter KT, Willbanks A, Heinzerling TJ, O’Leary RM, Xu X, Bass A, Chandar AK, Chak A, Elliott R, Willis JE, Markowitz SD and Grady WM: Subtypes of Barrett's oesophagus and oesophageal adenocarcinoma based on genome-wide methylation analysis. Gut 68(3): 389-399, 2019. PMID: 29884612. DOI: 10.1136/gutjnl2017-314544

32 Panda A, Shin MR, Cheng C and Bajpai M: Barrett's epithelium to esophageal adenocarcinoma: is there a "point of no return"? Front Genet 12: 706706, 2021. PMID: 34603373. DOI: $10.3389 /$ fgene. 2021.706706

33 Ilie M, Long-Mira E, Bence C, Butori C, Lassalle S, Bouhlel L, Fazzalari L, Zahaf K, Lalvée S, Washetine K, Mouroux J, Vénissac N, Poudenx M, Otto J, Sabourin JC, Marquette CH, Hofman V and Hofman P: Comparative study of the PD-L1 status between surgically resected specimens and matched biopsies of NSCLC patients reveal major discordances: a potential issue for anti-PD-L1 therapeutic strategies. Ann Oncol 27(1): 147-153, 2016. PMID: 26483045. DOI: 10.1093/annonc/mdv489

34 Wang L, Zhang Q, Ni S, Tan C, Cai X, Huang D and Sheng W: Programmed death-ligand 1 expression in gastric cancer: correlation with mismatch repair deficiency and HER2-negative status. Cancer Med 7(6): 2612-2620, 2018. PMID: 29673110. DOI: $10.1002 / \mathrm{cam} 4.1502$

35 de Klerk LK, Patel AK, Derks S, Pectasides E, Augustin J, Uduman M, Raman N, Akarca FG, McCleary NJ, Cleary JM, Rubinson DA, Clark JW, Fitzpatrick B, Brais LK, Cavanaugh ME, Rode AJ, Jean MG, Lizotte PH, Nazzaro MJ, Severgnini M, Zheng H, Fuchs CS, Enzinger PC and Bass AJ: Phase II study of pembrolizumab in refractory esophageal cancer with correlates of response and survival. J Immunother Cancer 9(9): e002472, 2021. PMID: 34593617. DOI: 10.1136/jitc-2021002472
36 Dhakras P, Uboha N, Horner V, Reinig E and Matkowskyj KA: Gastrointestinal cancers: current biomarkers in esophageal and gastric adenocarcinoma. Transl Gastroenterol Hepatol 5: 55, 2020. PMID: 33073050. DOI: 10.21037/tgh.2020.01.08

37 Morrow MP, Kraynyak KA, Sylvester AJ, Dallas M, Knoblock D, Boyer JD, Yan J, Vang R, Khan AS, Humeau L, Sardesai NY, Kim JJ, Plotkin S, Weiner DB, Trimble CL and Bagarazzi ML: Clinical and immunologic biomarkers for histologic regression of high-grade cervical dysplasia and clearance of HPV16 and HPV 18 after immunotherapy. Clin Cancer Res 24(2): 276-294, 2018. PMID: 29084917. DOI: 10.1158/1078-0432.CCR-17-2335

38 Almhanna K, Rosa M, Henderson-Jackson E, Jiang K, Shamekh R, Sayegh Z, Malafa MP and Coppola D: Her-2 expression in gastroesophageal intestinal metaplasia, dysplasia, and adenocarcinoma. Appl Immunohistochem Mol Morphol 24(9): 633-638, 2016. PMID: 26186253. DOI: 10.1097/PAI.000000 0000000243
Received October 25, 2021

Revised December 23, 2021

Accepted January 4, 2022 